\title{
Photoselective-Light Impacts on Fruit Bagging Microclimate, Quality, and Nutrients of Peach
}

\author{
David Campbell, Jeffrey K. Brecht, and Ali Sarkhosh \\ Horticultural Sciences Department, University of Florida, 2550 Hull \\ Road, Gainesville, FL 32611
}

Oscar Liburd

Entomology and Nematology Department, University of Florida, 1881 Natural Area Drive, Gainesville, FL 32608

\section{Danielle Treadwell \\ Horticultural Sciences Department, University of Florida, 2550 Hull Road, Gainesville, FL 32611}

Additional index words. anthocyanin, cyanidin-3-glucoside, low-chill, photoselective, Prunus persica, 'TropicBeauty', 'UFSun'

\begin{abstract}
The use of paper or nylon bags (fruit bagging) to surround tree fruit during development provides protection from a variety of pest-disease complexes for peach without yield reduction and different-colored bags have the potential to improve fruit quality based on findings from other crops. An experiment was conducted in 2019 at two locations in central Florida on peach [Prunus persica (L.) Batch] 'TropicBeauty' and 'UFSun' to analyze the impact of a commercially available white paper fruit bag combined with a photoselective insert. The insert reduced the amount of light outside the spectrum range of interest for blue $(400-500 \mathrm{~nm})$, green $(500-600 \mathrm{~nm})$, or red $(>600 \mathrm{~nm})$ wavebands, or decreased fluence rate with a neutral density black $(>725 \mathrm{~nm})$ insert. Relative to ambient, temperature inside all bagging treatments during the daytime hours was increased by $5.1^{\circ} \mathrm{C}$. During the same time, relative humidity was reduced by $10.1 \%$, but calculations revealed that the water vapor pressure was elevated only for treatments that had a plastic colored (blue, green, or red) insert. An orthogonal contrast revealed that the elevated water vapor around the fruit in a colored bag increased the concentration of chlorophyll at harvest but had no effect on other quality parameters. Compared with unbagged fruit, red-bagged fruit were 1.8 times firmer and green-bagged fruit and had a lower peel chroma. White-bagged (without photoselective insert) fruit had similar nutrient concentrations for the peel, flesh, and pit when compared with unbagged fruit. When bags remained on the fruit until harvest, anthocyanin concentration in unbagged fruit peel was double the amount in white bags and 6-fold more than the bags with color inserts. Different-colored bagging treatments did not influence insect attraction or fruit quality parameters, such as fruit size, diameter, difference of absorbance (DA) index, total soluble solids (TSS), titratable acidity (TA), pH, peel lightness, peel hue, flesh lightness, flesh hue, or flesh chroma. Relative to full sun, the colored bag treatments allowed between $3.7 \%$ (black) and $17.4 \%$ (red) of the photosynthetically active radiation (PAR). Additional research is needed to determine if an increase in fluence rate at specific spectral wavelengths can affect the quality for peach grown in bags in the field.
\end{abstract}

Manually bagging peach fruit has shown promise to reduce pest and pathogen injury with minimal risk to yield reduction (Allran et al., 2019; Campbell et al., 2021; Sharma et al., 2014). Bags used in research and practice are typically constructed of paper or polypropylene. The physical covering changes the environment in the area surrounding the fruit, or the carposphere, and the associated alterations in light, temperature, and humidity can affect fruit quality. Several studies have identified specific wavelengths of light that stimulate photoreceptors, which may improve fruit quality attributes such as size, color, TSS, anthocyanin content, and other quality factors (Folta and Carvalho, 2015; Holopainen et al., 2018; Olle and Viršile, 2013).
Plants contain chlorophyll that converts light into chemical energy, but light does more than provide energy for metabolism. Plants contain specific pigments, namely the phytochromes, cryptochromes, phototropins, and other photoreceptors that are activated by specific light wavelengths, and drive discrete changes in gene expression, physiology, and metabolism. These photoreceptor classes are activated in response to specific wavebands, but taken as a whole have activity from the ultraviolet (Magerøy et al., 2010; Reyes et al., 2020), visible, and near infrared (Johnson et al., 1996) spectra. Plant growth, development, morphology, and metabolism may be altered by enhancing or omitting wavelengths, as demonstrated using light-emitting diode
(LED) technology (Olle and Viršile, 2013), as well as with colored nets (Manja and Aoun, 2019), reflective mulches (Kasperbauer, 2000), or bags (Sharma et al., 2014). Research using LED technology has provided the most detailed information on plant responses because narrow-bandwidth light can be projected in a controlled indoor environment to isolate plant responses. Reviews on photoreceptor activity and biochemical reactions (Folta and Carvalho, 2015), as well as phytochemical production (Holopainen et al., 2018; Olle and Viršile, 2013), detail the impact LED technology can have on protein structural changes, secondary metabolite accumulation, vegetative growth, reproductive growth, nutrient uptake, and plant defenses. For example, lettuce (Lactuca sativa) leaves accumulated more $\mathrm{Cu}, \mathrm{Fe}, \mathrm{K}, \mathrm{Mn}$, and $\mathrm{Zn}$ under red LED lights. Under red + blue or white LED lights, $\mathrm{N}$ and $\mathrm{Mg}$ nutrient concentrations were increased in lettuce (Amoozgar et al., 2017). In far red light, hypocotyl elongation was observed in squash (Cucurbita maxima $\times$ Cucurbita moschata) (Yang et al., 2012) and tomato (Solanum lycopersicum) (Chia and Kubota, 2010). Under red light, anthocyanin concentration was increased for strawberry (Fragaria $\times$ ananassa) (Miao et al., 2016) and cabbage (Brassica oleracea) (Mizuno et al., 2011), but showed mixed results for lettuce ( $\mathrm{Li}$ and Kubota, 2009; Samuoline et al., 2012; Stutte et al., 2009). Both blue and green light decreased anthocyanin concentration in strawberry (Miao et al., 2016).

Measuring plant responses to changes in specific wavebands for field-grown tree crops is more complicated than for crops grown in controlled environments due to the diurnal light changes, unpredictable weather, and other practical difficulties. Techniques such as whole tree netting for field-grown tree crops (Mupambi et al., 2018) and bagging individual fruit (Sharma and Sanikommu, 2018) have been evaluated under different photoselective light conditions. Like netting, LED lighting affects the entire plant or tree, whereas bagging only affects the carposphere around the fruit. Different construction materials used for either netting or bagging can effectively change the spectrum of light that reaches the plant (Bastías and Corelli-Grappadelli, 2012). Shahak et al. (2004) found that netting peach trees with blue or red nets decreased the canopy temperature. Blue and white nets had no effect on fruit weight, whereas red netting increased fruit weight and both white and red nets increased vegetative growth.

In studies with apple, it was found that paper bagging increased internal bag temperatures (Ritenour et al., 1997). In peach bagging studies in which plastic bags with perforations were evaluated, it was found that relative humidity $(\mathrm{RH})$ and temperature increased in the bag (Li et al., 2001; Morandi et al., 2010). The increased RH was associated with reduced transpiration and smaller fruit weight, which the authors speculated was due to a reduced xylem flow and lower sugar loading in the fruit (Morandi et al., 2010). Liu et al. (2015) found that peach anthocyanin content was reduced for black, blue, and gray bags, but was 
increased for white bags and unbagged fruit. Zhang et al. (2015) found that white paper and polypropylene bags resulted in similar amounts of anthocyanin when the bags remained on the fruit until harvest, and showed an increased amount of anthocyanin when black bags were removed $7 \mathrm{~d}$ before harvest. White-bagged peaches showed mixed results for fresh weight, chlorophyll content, organic acids, TSS, firmness, and peel color (Liu et al., 2015; Zhang et al., 2015).

In addition to potentially altering the fruit quality, different colors also impact insect pest attraction. Different-colored traps have been shown to attract beneficial lady beetles (Coleoptera: Coccinellidae) (Kemp and Cottrell, 2015) and stink bug pests (Hemiptera: Pentatomidae) (Bae et al., 2019; Hogmire and Leskey, 2006), but no effect was found when different-colored traps were placed in commercial peach orchards (Leskey and Hogmire, 2005). There is limited research on the attraction of arthropod pests to a wide range of colors in peach orchards and identifying offsetting effects of fruit quality changes with increased pest attraction will be useful practical information for growers.

There are extensive reports that demonstrate the positive impacts of reducing pest and disease injury for a variety of crops and the ability to alter plant physiology under different bagging and light conditions. The contribution of the current study is the evaluation of the impact of a wide range of modified light spectra conditions on peach fruit quality and insect attraction. The purpose of this project was to determine if different-colored bags alter the temperature, $\mathrm{RH}$, fruit quality, and known arthropod pest attraction for lowchill peach cultivars. This project tested the hypothesis that selective color filters within bags in the field can be used to affect the fruit quality of peach, such as increased anthocyanin for blue and red filters, decreased anthocyanin for black and green filters, and increased fruit size for red filters (Holopainen et al., 2018; Liu et al., 2015; Shahak et al., 2004; Wang and Folta, 2013). Parameters including temperature and $\mathrm{RH}$ inside the bag, insect attraction, and fruit quality parameters such as fresh weight, size, chlorophyll

Received for publication 26 Apr. 2021. Accepted for publication 2 Aug. 2021.

Published online 28 September 2021.

We thank Edzard van Santen, Professor of Agronomy and Director of the University of Florida Institute of Food and Agricultural Sciences Statistical Consulting Unit, for his statistical assistance. This work is supported by Organic Agriculture Research and Extension Initiative 2016-5130025726 from the U.S. Department of Agriculture National Institute of Food and Agriculture. Any opinions, findings, conclusions, or recommendations expressed in this publication are those of the author(s) and do not necessarily reflect the view of the U.S. Department of Agriculture.

D.T. is the corresponding author. E-mail: ddtreadw@ufl.edu.

This is an open access article distributed under the CC BY-NC-ND license (https://creativecommons. org/licenses/by-nc-nd/4.0/). content, TSS, TA, pH, flesh firmness, anthocyanin concentration, peel color, flesh color, and nutrient concentration were analyzed to determine if bagging can provide growers with a practical means to improve fruit quality.

\section{Materials and Methods}

Experimental sites. Research station and on-farm trials were conducted with 'TropicBeauty' and 'UFSun' peaches on 'Flordaguard' rootstock at a conventional peach orchard at the University of Florida/Institute of Food and Agricultural Science (UF/IFAS) Plant Science Research and Education Unit in Marion County, FL (lat. $29.408813^{\circ} \mathrm{N}$, long. $82.173041^{\circ} \mathrm{W}$, altitude $21 \mathrm{~m}$ ) and with 'TropicBeauty' peach on 'Flordaguard' rootstock at a U.S. Department of Agriculture-certifiedorganic peach orchard in Lake County, FL (lat. $28.608826^{\circ} \mathrm{N}$, long. $-81.750942^{\circ} \mathrm{W}$, altitude $34 \mathrm{~m}$ ) in 2019. The soils at both locations were deep and well drained with less than $2 \%$ soil organic matter and classified as a Sparr fine sand series soil type (loamy, siliceous, subactive, hyperthermic Grossarenic Paleudults) at the Marion County location and the Candler sand series soil type (Hyperthermic, uncoated Lamellic Quartzipsamments) at the Lake County location.

At the Marion County location, 'TropicBeauty' and 'UFSun' were planted in 2012 with a higher than typical density planting averaging 785 trees/ha. The orchard received $1121 \mathrm{~kg} \cdot \mathrm{ha}^{-1}$ of granular $10 \mathrm{~N}-0.4 \mathrm{P}-0.8 \mathrm{~K}$ in three band applications and four foliar micronutrient applications at $9.35 \mathrm{~L} \cdot \mathrm{ha}^{-1}$ (SOAR Peach Mix; Chemical Dynamics, Inc., Plant City, FL). For weed, insect, and fungal management, the site received monthly applications of $630 \mathrm{~g} \cdot \mathrm{ha}^{-1}$ a.i. of paraquat dichloride (Parazone 3SL Herbicide; AMVAC, Los Angeles, CA), three applications of $140 \mathrm{~g} \cdot \mathrm{ha}^{-1}$ a.i. of spirotetramat (Movento; Bayer CropScience, Monheim am Rhein, Germany), and two applications of $1684 \mathrm{~g} \cdot \mathrm{ha}^{-1}$ a.i. of chlorothalonil (Bravo; Syngenta, Basel, Switzerland), respectively. Only 'TropicBeauty' was evaluated at the Lake County site, and the layout and management have been previously described by Campbell et al. (2021). In short, the trees were planted to a density of 289 trees/ ha and managed as a certified-organic U-pick orchard with the same $\mathrm{N}$ rate applied as at the Marion County location and organic compliant fungicides and pesticides.

Experimental design. The initial experimental design consisted of two factors: cultivar ( 2 levels: 'UFSun' and 'TropicBeauty') and bag color (6 levels: see the following) at two locations, with treatments arranged in a completely randomized design with six replicates (individual trees served as a replicate). However, the field cultivar map used at the time of bagging was incorrect and due to the similarity of phenology between 'UFSun' and 'TropicBeauty', the cultivars were misidentified and only 'TropicBeauty' was bagged at the Lake County site. The error was recognized halfway through the season. and although the resulting design was imbalanced in its representation of cultivars, a modified approach to statistical analysis was developed in consultation with a statistician. The modified design assessed bag removal for 'TropicBeauty' at two levels [7 d before harvest $(\mathrm{DBH})$ and at harvest $(0 \mathrm{DBH})]$ at the Lake County site only. Cultivars were correctly identified and bagged at the Marion County site. The final experimental design included the factors cultivar (2 levels) and bag color (6 levels) at the Marion County site and bag removal (2 levels) and bag color (6 levels) at the Lake County site. The experiment consisted of four different location/cultivar/bag removal combinations (heretofore referred to as a site combination). At each site, replications consisted of a single tree with all factor combinations and fruit from 12 trees at each site were assessed.

At each site combination, the main factor of bag color was randomly assigned to eight individual fruit per tree at six levels: no bag (control), white paper (WP) bag only, and four color levels (blue, green, red, and black) that consisted of the WP bag with a $20 \mathrm{~cm} \times$ $10 \mathrm{~cm}$ photoselective colored film or a polyester microfiber insert (Fig. 1). Microfiber
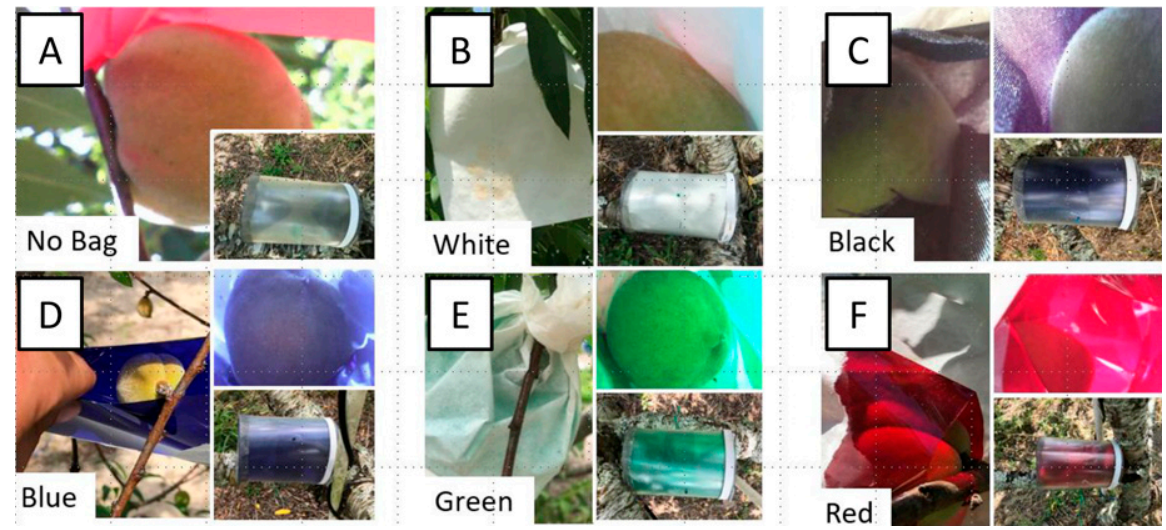

Fig. 1. Photographs taken in the field of colored bagging treatments with the background photograph outside of the bag, top right taken inside the bag with a telescopic camera, and bottom right taken of the color-baited insect traps of the unbagged control (A), white paper bag (WB) only (B), black insert + WB (C), blue insert + WB (D), green + WB (E), and + WB (F). Photo courtesy of author, D. Campbell. 


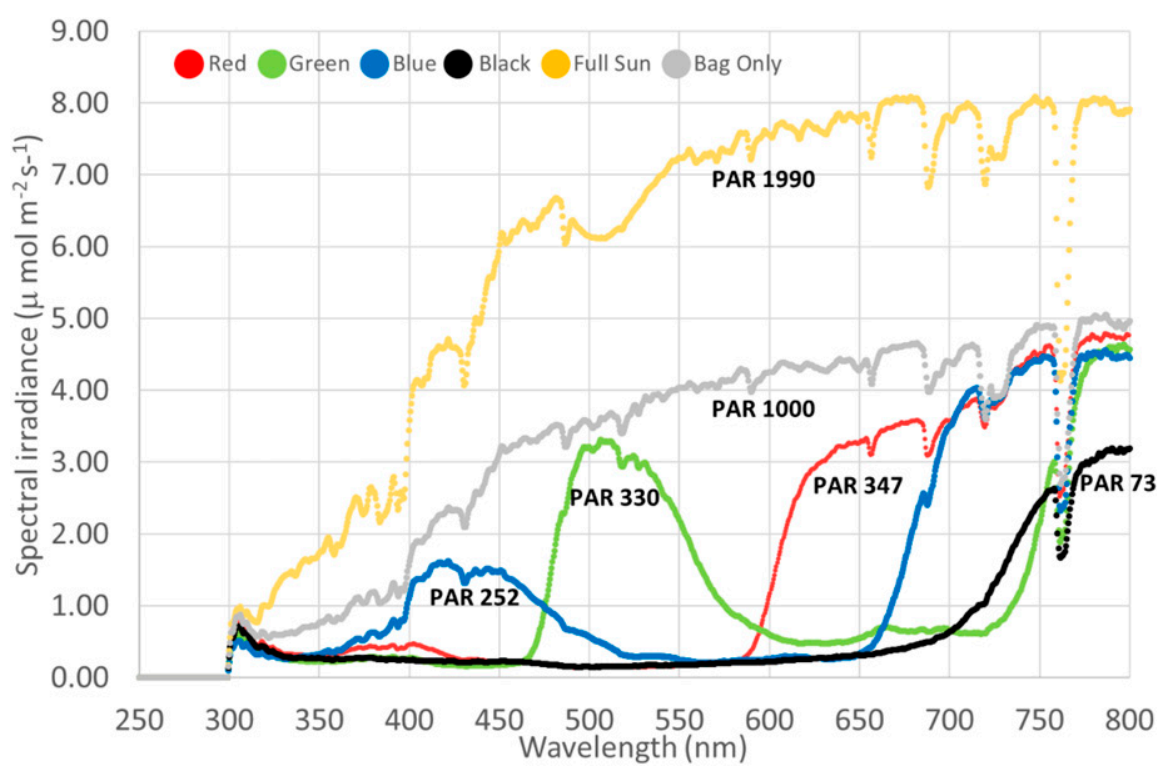

Fig. 2. Spectral irradiance of full sun, white paper bag only (bag only), and photoselective inserts while inside a white paper bag for the treatments: red, green, blue, and black. Photosynthetically active radiation $(P A R)$ values listed below each measurement.

was used for the black treatment because the desired spectrum was not available in plastic film and the hydrophobic nature of microfiber would avoid moisture retention within the bag, which was similar to the other photoselective inserts. The total $P A R$ and transmitted light spectrum through the WP bag plus photoselective insert (Fig. 2) was verified to confirm wavelengths outside of the range of interest were reduced for treatments with relatively increased wavelengths at 400 to 500 nm, blue (roscolux \#4290; Rosco, Stamford, $\mathrm{CT}$ ); 500 to $600 \mathrm{~nm}$, green (roscolux \#389); $>600 \mathrm{~nm}$, red (roscolux \#26), and >725 nm, black (black microfiber; American Home Collection, Maspeth, NY) by a spectroradiometer (Apogee/Stellarnet, Logan, UT).

Bag installation and harvest. Full bloom for 'UFSun' was observed on 24 Jan. 2019 and between 29 and 31 Jan. 2019 for 'TropicBeauty'. Fruit were thinned according to standard grower practices (Chang et al., 2018). Within $3 \mathrm{~d}$ of protective insecticide and fungicide applications (see earlier in this article), eight fruitlets that measured between 3 and $4 \mathrm{~cm}$ along the stem-blossom axis were bagged between 28 Feb. 2019 and 11 Mar. 2019. The sequence of bagging level and direction traveled around the tree was randomly assigned for each tree resulting in a random and even distribution of color treatments around the canopy perimeter. Fruit were bagged on the tree's outermost perimeter at a height between 1 and $2 \mathrm{~m}$ and the photoselective material inside the bag was manually rotated to ensure that incident light would pass through the photoselective filter before reaching the peach surface (Fig. 1). Unbagged fruit were identified by wrapping pink tape around the branch proximal to the selected fruit (Fig. 1). In general, 'UFSun' matured $\approx 10 \mathrm{~d}$ before 'TropicBeauty', and the more southerly Lake County site matured $9 \mathrm{~d}$ before the Marion County site. Bagging procedures were previously described by Campbell et al. (2021). Based on grower recommendations, tactile observations of softening fruit tips, increased blush of unbagged fruit, and decreased chlorophyll readings for all site combinations that included a bag removal 7 DBH (DA Index below 40 was determined optimal based on research and observations conducted in 2018), three harvests of tree-ripened fruit occurred between 23 Apr. 2019 and 9 May 2019, and the fruit were transported in a climate-controlled vehicle to the Postharvest Physiology Laboratory at UF/IFAS (Gainesville, FL).

To test insect pest attraction to these color levels, photoselective inserts were inserted inside double-conical insect traps that effectively capture stink bug pests (Hemiptera: Pentatomidae) (Fig. 1). Three replications (18 total color-baited traps) were installed on 'TropicBeauty' scaffold branches at the Lake County location. Color-baited insect traps were monitored every 2 weeks.

Meteorological, soil, and leaf nutrient data. Weather data for 2018 and 2019 were collected from the closest Florida Automated Weather Network (FAWN, 2019) weather station for the Lake County location (28.681 $650^{\circ} \mathrm{N},-81.885650^{\circ} \mathrm{W}$, altitude $27 \mathrm{~m}$ ), which was located $\approx 15.5 \mathrm{~km}$ northeast of the orchard and onsite at the Marion County location. Measurements and associated comparisons of temperature, $\mathrm{RH}$, and water vapor pressure inside the colored bag treatments were collected with temperature/RH sensors (HOBO MX2302A; Onset Computer, Bourne, MA) that had an air and dew point temperature accuracy of $\pm 0.2^{\circ} \mathrm{C}$ and $\mathrm{RH}$ accuracy of $\pm 0.25 \%$. A single sensor for all treatments was installed on three replicates of 'UFSharp' trees (18 sensors in total), which provided information beyond the maturation dates of 'UFSun' and 'TropicBeauty'. Sensors were installed on 21 Mar. 2019 under the filter and above the fruit to avoid shading and remained inside the bag throughout the duration of the season until removal on 17 May 2019. Sensors that served as an unbagged control were placed adjacent to fruit on the same tree and were installed with a sun-shield as recommended by the manufacturer to ensure the integrity of the sensor. Dew point temperature collected from the sensors was used to calculate the amount of water vapor pressure (WVP) inside the bags based on a formula provided by the $\mathrm{Na}$ tional Weather Service National Ocean and Atmospheric Administration (https://www. weather.gov/epz/wxcalc_vaporpressure) as outlined in the following equation:

$$
\mathrm{WVP}=6.11^{*} 10^{\wedge}\left(7.5^{*} \mathrm{~T}_{\mathrm{d}} / 237.3+\mathrm{T}_{\mathrm{d}}\right),
$$

where $\mathrm{WVP}=$ water vapor pressure, and $\mathrm{T}_{\mathrm{d}}=$ dew point temperature.

Soil and leaf tissue nutrient analyses were conducted immediately after fruit harvest to determine nutrient status and eliminate any confounding factors (data not shown but will be available online at the UF dissertation repository in 2023). At each site combination, 10 soil cores collected with a $2.5-\mathrm{cm}$ diameter probe to $10 \mathrm{~cm}$ deep were bulked, mixed, and submitted to the UF/IFAS Analytical Research Laboratory (Gainesville, FL) for analysis with a Mehlich-3 extraction. At each site combination, 30 first-fully expanded mature leaves and petioles from each tree were collected and submitted for nutrient analysis (Waypoint Analytical Laboratory, Mulberry, FL).

Fruit physical, compositional, and nutrient analysis. Three fruit from each color treatment were harvested within $\approx 3 \mathrm{~d}$ of being ripe and ready for consumption. Transport from orchards to laboratory and procedures for fruit quality analyses of weight, diameter, peel color, flesh color, chlorophyll content, flesh firmness, $\mathrm{pH}$, TSS, and TA measurements were identical to those described in Campbell et al. (2021). Peel and flesh color measurements of lightness, hue, and color were directly reported or calculated according to the CIE $\mathrm{L}^{*} \mathrm{a} * \mathrm{~b}$ scale. In short, measurements (by instrument) of weight (Mettler Toledo, Columbus, $\mathrm{OH}$ ), diameter (EW97152; Cole-Parmer, Vernon Hills, IL), peel color (Minolta CR-400; Marunouchi, Chiyoda, Tokyo, Japan), and DA Index (DA Meter; Sinteleia, Bologna, Italy) were taken on the day of harvest and after storage at $3{ }^{\circ} \mathrm{C}$ for up to $48 \mathrm{~h}$. Fruit were allowed to warm to room temperature, peeled to expose a circular area $\approx 2.5 \mathrm{~cm}$ in diameter, assessed for flesh color and firmness (TA HD plus texture analyzer; Texture Technologies, Inc., Hamilton, MA), peel tissue collected for anthocyanin analysis (see anthocyanin analysis in the next section), and two longitudinal slices along the stem-blossom axis were removed and stored at $-30^{\circ} \mathrm{C}$. Within $30 \mathrm{~d}$, fruit slices were thawed but kept cold and then blended (commercial blender; Hamilton Beach, Glen Allen, VA) and the resulting slurry was centrifuged at $22,217 g_{\mathrm{n}}$ at $4{ }^{\circ} \mathrm{C}$ for $10 \mathrm{~min}$ and the supernatant (juice) was decanted. 
Measurements of $\mathrm{pH}$ and TA (814 USB Sample Processor; Metrohm, Herisau, Switzerland), and TSS (Reichert Ametek, Berwyn, PA) were performed using the supernatant.

Anthocyanin analysis. Peaches were peeled to a depth of $1 \mathrm{~mm}$ along the midpoint of the stem-blossom end around the entire circumference of the peach. Additional peel that was most representative of overall peel color was collected to yield $5 \pm 0.5 \mathrm{~g}$ and stored at $-30^{\circ} \mathrm{C}$. Anthocyanin extraction (modified from Lee et al., 2005) and measurements were conducted under a yellow light that reduced the degradation of anthocyanin. Before peach sample preparation, the extraction solution $[370 \mathrm{~mL}$ deionized (DI) water, $30 \mathrm{~mL}$ formic acid, and $600 \mathrm{~mL}$ methanol], a solution at $\mathrm{pH} 4.5(880 \mathrm{~mL}$ DI water, $54.4 \mathrm{~g}$ sodium acetate, $20 \mathrm{~mL} 1.5 \mathrm{~N} \mathrm{HCl})$, and a solution at $\mathrm{pH} 1.0(990 \mathrm{~mL}$ DI water, $1.86 \mathrm{~g}$ $\mathrm{KCl}, 8.3 \mathrm{~mL} 1.5 \mathrm{~N} \mathrm{HCl}$ ), were prepared and stored at $2{ }^{\circ} \mathrm{C}$. Before extraction, the frozen peach peel was thawed but kept on ice while not being processed. Thawed peel $(1.5 \pm$ $0.15 \mathrm{~g}$ ) was homogenized (OMNI bead rupter elite homogenizer; OMNI International, Kennesaw, GA) in $15 \mathrm{~mL}$ of the extraction solution. Successful homogenization was achieved when, on visual observation, the peel was uniformly disassociated, and homogenate peel pieces were less than $2 \mathrm{~mm}$ wide. The homogenate and solution were left to passively extract the anthocyanin for $20 \mathrm{~min}$ while in an ice bath. Next, the solution was centrifuged at $15,428 g_{\mathrm{n}}$ at $4{ }^{\circ} \mathrm{C}$ for $10 \mathrm{~min}$ and $0.3 \mathrm{~mL}$ of supernatant was pipetted into prefilled test tubes (containing $2.7 \mathrm{~mL}$ of either the $\mathrm{pH} 4.5$ or $\mathrm{pH} 1.0$ solution). The combined supernatant and $\mathrm{pH} 4.5$ and 1.0 solutions were vortexed for $20 \mathrm{~s}$ and allowed to equilibrate for $15 \mathrm{~min}$ at room temperature $\left(24^{\circ} \mathrm{C}\right)$. After equilibration, $200-\mu \mathrm{L}$ samples of the supernatant- $\mathrm{pH}$ solution samples and deionized water blanks were loaded into non-ultraviolet-compatible microplates. Microplates were loaded into a Powerwave XS2 spectrophotometer (BioTek Instruments, Inc., Winooski, VT) and the absorbance was read at $510 \mathrm{~nm}$ and $700 \mathrm{~nm}$ with a path-length correction. The concentration of the most prominent anthocyanin in peach fruit, cyanidin-3-glucoside (C-3-G), was calculated based on the approach described by Lee et al. (2005) and Jurd and Asen (1966), as outlined in the following equation:

$\mathrm{C}-3-\mathrm{G}\left(\mathrm{mg} \cdot \mathrm{L}^{-1}\right)=(\mathrm{A} * \mathrm{MW} * \mathrm{DF} * 1000) / \mathrm{L}^{*} \alpha$

where A (absorbance) $=[\mathrm{A} 510(\mathrm{pH} 1)-$ $\mathrm{A} 700(\mathrm{pH} 1)]-[\mathrm{A} 510(\mathrm{pH} 4.5)-\mathrm{A} 700(\mathrm{pH} 4.5)]$; MW (molecular weight) $=449.2 \mathrm{~g} \cdot \mathrm{mol}^{-1}$ for C-3-G; DF (dilution factor) $=$ (solvent + peel $) /($ peel $*(\mathrm{pH}$ solution + supernatant $) /$ supernatant); $\mathrm{L}=1 \mathrm{~cm}$; and $\alpha=26,900$ $\mathrm{L} \cdot \mathrm{mol}^{-1} \cdot \mathrm{cm}^{-1}$.

Nutrient analysis. Two 'TropicBeauty' fruit from the white-bagged (removed 7 $\mathrm{DBH}$ ) and unbagged control from each replication at both locations were selected for nutrient composition analysis. Fruit peel was removed to a depth of $1 \mathrm{~mm}$ and flesh was separated from pits for all fruit before drying in a forced-air oven at $65^{\circ} \mathrm{C}$ until dry (at a constant weight). Dried peel and flesh samples were unprocessed, but dried pit samples were ground to less than $1 \mathrm{~mm}$ using a Wiley Mill (Thomas Scientific, Swedesboro, NJ) before nutrient analysis (Waypoint Analytical Laboratory, Mulberry, FL).

Statistical analyses. Linear mixed model assumptions of linearity, normality, and homogeneity of variance were satisfied before analysis of variance (ANOVA). Two ANOVAs were conducted, the replicated site combination of 'TropicBeauty' with the bag removed $7 \mathrm{DBH}$ and each single-site combination analysis using the GLIMMIX procedure of SAS (v 9.4; SAS Institute, Cary, NC). The statistical model for the single-site combinations was improved by analyzing variables that had covariance parameters with a $\chi^{2}$ at $P \leq$ 0.05 separately to account for heterogeneity between site combinations. Temperature, $\mathrm{RH}$, and WVP were analyzed as a contrast between each colored bag and the control. When significant at $P \leq 0.05$, means were separated using Tukey's honestly significant difference method. Differences and interactions between cultivar and bag removal date factors were not analyzed because they would not provide additional information regarding the effects of different color treatments.

\section{Results}

Site conditions. The orchard naturally defoliated by 1 Dec. 2018, and the first budbreak was observed on 10 Jan. 2019. During dormancy, the orchards received 67 and $105 \mathrm{~h}$ between $0{ }^{\circ} \mathrm{C}$ and $7.2^{\circ} \mathrm{C}$ in Lake County and Marion County locations, respectively. The average air temperature (measured at $2 \mathrm{~m}$ above the ground) and the average daily temperature and total precipitation for the growing cycle between full bloom and the first harvest were $18.0^{\circ} \mathrm{C}$ and $307.6 \mathrm{~mm}$ at the Marion County location and $19.4^{\circ} \mathrm{C}$ and $207.3 \mathrm{~mm}$ at the Lake County location (Fig. 3). Soil and leaf nutrient levels from field-collected samples indicated that nutrient deficiency was not a limiting factor at either location (Johnson, 2008; data not shown but will be available
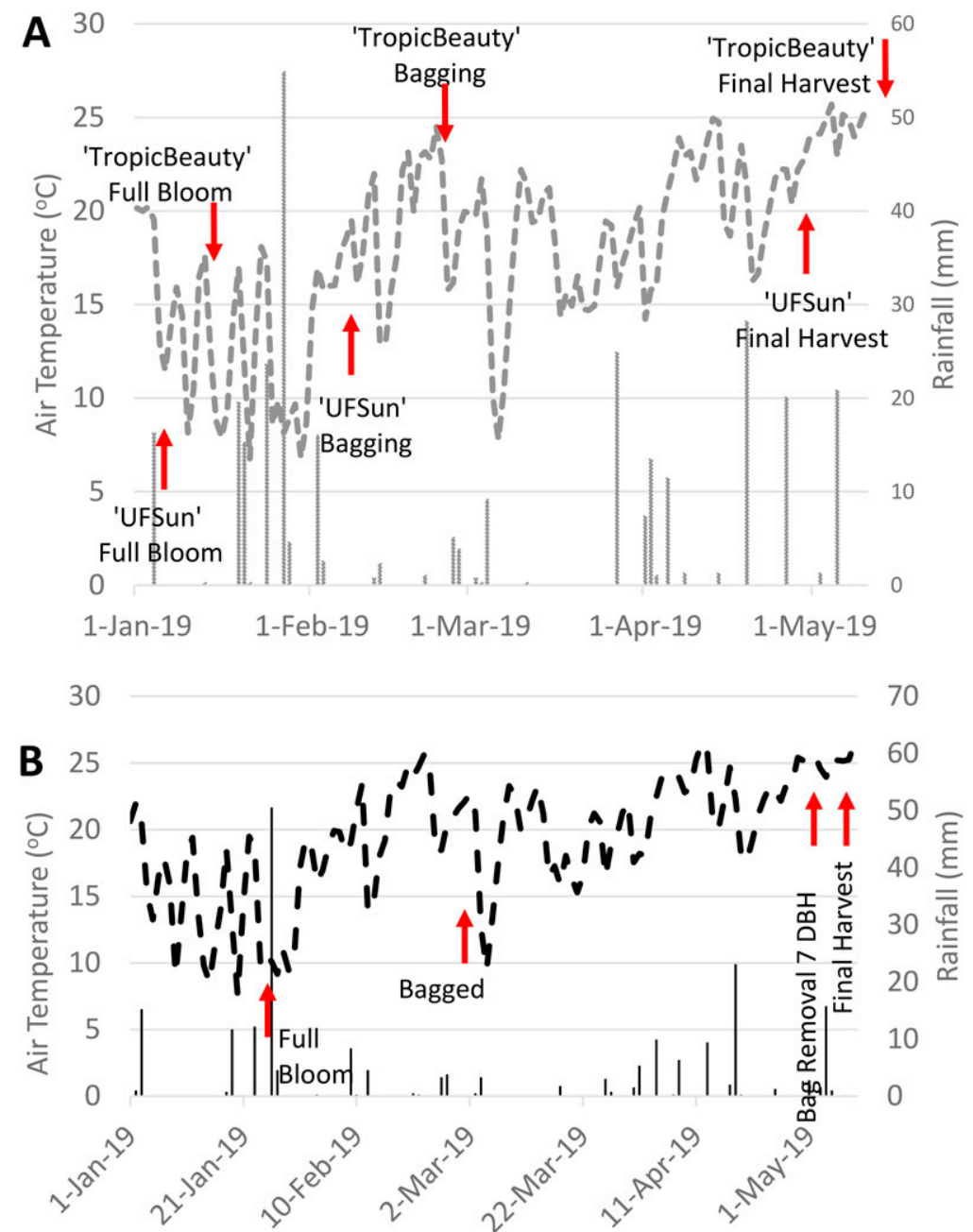

Fig. 3. Average daily temperature and rainfall in central Florida during peach fruit growth in (A) Marion County (1 Jan. 2018 to 10 May 2018), with arrows representing dates corresponding to full bloom, bagging date, and the final fruit harvest for 'UFSun' and 'Tropic Beauty'; and (B) Lake County (1 Jan. 2019 to 10 May 2019), with arrows representing dates corresponding to full bloom, bagging date, bag removal at $7 \mathrm{~d}$ before harvest $(7 \mathrm{DBH})$, and the final fruit harvest. 

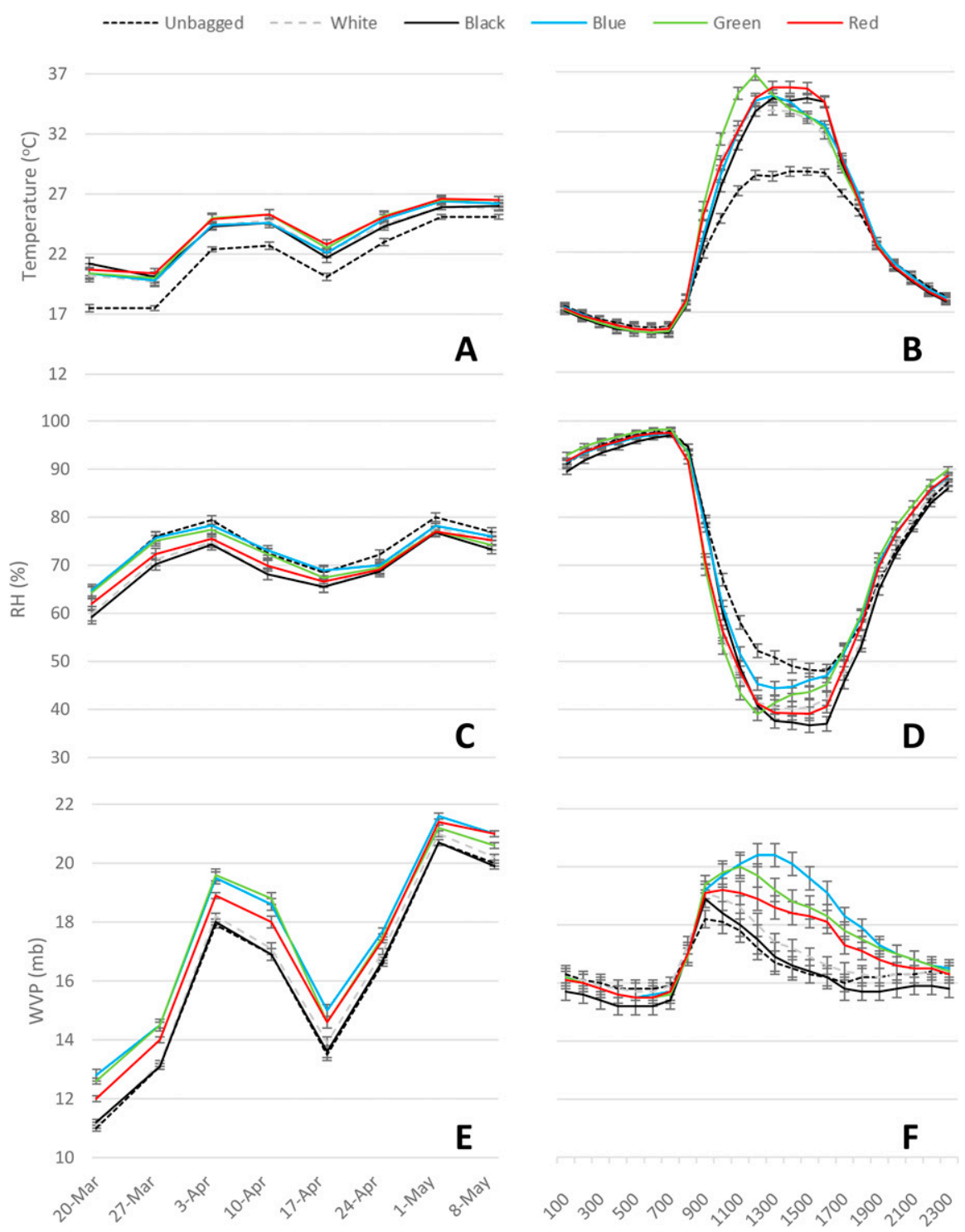

Fig. 4. Temperature (A and B), RH (C and D), and water vapor pressure (WVP) (E and $\mathbf{F}$ ) around unbagged 'UFSharpe' peach fruit and inside bags containing fruit grown in Marion County in 2019. Data were averaged by week (left column) and over the year, and presented on an hourly basis (right column). Data are presented as means with bars representing the SE. Differences $(P \leq 0.05)$ are discussed in the text.

online at the UF dissertation repository in 2023).

Air temperature, $R H$, and WVP in bags. When averaged over a weekly basis, the internal bag temperatures for all treatments were consistently elevated throughout the growing season $(P \leq 0.05)$, but the magnitude of temperature increase declined throughout the season for all treatments (Fig. 4). For example, the internal white bag temperature was $3.3^{\circ} \mathrm{C}$ higher than the control outside air temperature during the week of 20 Mar. 2019, but was only $0.8^{\circ} \mathrm{C}$ higher than the control during the week of 9 May 2019. Temperatures averaged across the entire season and analyzed on an hourly basis inside the bags were consistently elevated between $900 \mathrm{HR}$ and $1800 \mathrm{HR}$ for all treatments $(P \leq$ $0.033)$ except for the black at $0900 \mathrm{HR}(P=$ 0.086 ). The sun rose between $0638 \mathrm{HR}$ and 0724 HR over the course of the experiment and the average temperature increase inside all bags was $5.1^{\circ} \mathrm{C}$ (Fig. 4). Relative to ambient, the average $\mathrm{RH}$ levels inside the bags were generally reduced for all treatments throughout the study. In the early season (between 28 Mar. and 17 Apr.), the RH levels within the white $(P<0.05)$, black $(P<$ $0.01)$, and red $(P<0.05)$ bags were lower than ambient. Later in the season (between 25 Apr. to 8 May), black $(P<0.05)$, green $(P<0.05)$, and red $(P<0.05)$ had lower RH than ambient (Fig. 4). On an hourly basis, all treatments had a reduced RH from $1000 \mathrm{HR}$ to 1400 HR $(P \leq 0.036)$, averaging $10.1 \%$ lower $\mathrm{RH}$ than ambient. Reduced RH was observed immediately outside of this time frame for one or multiple treatments from 0800 to $1800 \mathrm{HR}$ (excluding blue) $(P \leq 0.036)$. Relative to the ambient the average WVP was increased for the blue, green, and red treatments for the entire experiment $(P \leq 0.001)$. On an hourly basis, WVP was increased for blue, green, and red from $1000 \mathrm{HR}$ to $1800 \mathrm{HR}(P \leq 0.032)$.

Fruit physical and compositional attributes. The pairwise comparison of 'TropicBeauty' at two locations with the bag removed 7 DBH revealed that most physical and compositional characteristics did not change in response to bag color (Tables 1 and 2), but differences were observed between sites. There were no significant interactions between bag color and location for any measured fruit physical and compositional attributes. Fruit in red bags were 1.8 times more firm than unbagged fruit. Fruit peel chroma (a measure of color saturation or intensity) was greater for unbagged fruit than for green-bagged fruit (Table 1). Fruit from Marion County were 5.1 $\mathrm{mm}$ larger in diameter $(P \leq 0.001), 22 \mathrm{~g}$ heavier $(P \leq 0.001)$, and had $2.5 \%$ lower TSS $(P \leq 0.001)$ than fruit from Lake County. Fruit from Marion County also had slightly higher color measurements of peel chroma ( $P=$ $0.012)$, flesh chroma $(P=0.005)$, and flesh lightness $(P \leq 0.001)$. Bag color and growing location did not impact DA Index, TA, pH, anthocyanin concentration, peel lightness, peel hue, and flesh hue.

Analysis at each site combination level revealed no differences between the cultivars grown in Marion County. In Lake County, only flesh firmness showed differences when the bags were removed $7 \mathrm{DBH}$. At this site combination, green- and red-bagged fruit were $\approx 2.4$ times firmer than the control $(P=$ 0.004 ) (Fig. 5). When bags remained on the fruit until harvest $(0 \mathrm{DBH})$, multiple differences were observed. The unbagged control had double the anthocyanin content of the white-bagged group and $\approx 6$ times more than the other colored bags $(P=0.002)$ (Fig. 5); all bagging treatments had lighter peel than the control, and all colored bag treatments were lighter than the white bag $(P \leq 0.001)$ (Fig. 5); in addition, all bagging treatments had a greater peel hue (more yellow) than the control $(P \leq 0.001)$ (Fig. 5). Peel chroma showed a pattern that was similar to peel hue for all colored bagging treatments $(P=$ 0.003 ) (data not shown). At each site combination level, bag color did not affect fresh weight, fruit diameter, DA Index, TSS, TA, $\mathrm{pH}$, flesh lightness, or flesh hue.

Peach peel, flesh, and pit nutrient analysis. Peach peel and flesh nutrient content was unaffected by bagging color or by a bagging color*location interaction. Peel nutrient analysis showed $34 \%$ to $43 \%$ greater amounts of $\mathrm{N}, \mathrm{S}, \mathrm{P}, \mathrm{K}, \mathrm{Mg}$, and $\mathrm{Mn}$ at the Marion County location than at the Lake County location, but $389 \%$ more $\mathrm{Cu}$ in the peel of fruit at the Lake County location (Table 3). Flesh nutrient analysis showed $14 \%$ to $65 \%$ greater amounts of $\mathrm{N}, \mathrm{P}, \mathrm{K}, \mathrm{Mg}, \mathrm{Ca}$, and $\mathrm{B}$ at the Marion County location than at Lake County, but $32 \%$ and $171 \%$ greater amounts of $\mathrm{Zn}$ and $\mathrm{Cu}$, respectively, at the Lake County location (Table 3). Pit nutrient analysis showed a $33 \%$ increase in $\mathrm{S}$ at the Marion County location (Table 3 ).

Insect monitoring. Insect traps were installed on 12 Mar. 2019 and removed at final 
Table 1. Physical and chemical attributes of 'Tropic Beauty' peach fruit grown inside white paper bags (no filter) or with photoselective filters to alter the spectrum black $(>725 \mathrm{~nm})$, blue $(400-500 \mathrm{~nm})$, green $(500-600 \mathrm{~nm})$, and red $(>600 \mathrm{~nm})$ relative to full-spectrum light in Marion and Lake Counties in central Florida in 2019.

\begin{tabular}{|c|c|c|c|c|c|c|c|c|}
\hline Bag color & Fresh wt $(\mathrm{g})$ & $\operatorname{Diam}(\mathrm{mm})$ & DA index ${ }^{z}$ & $\mathrm{TSS}^{\mathrm{y}}$ & $\mathrm{TA}^{\mathrm{x}}$ & $\mathrm{pH}^{\mathrm{w}}$ & Flesh firmness $(\mathrm{N})$ & $\mathrm{C}-3-\mathrm{G}^{\mathrm{v}}\left(\mathrm{mg} \cdot \mathrm{L}^{-1}\right)$ \\
\hline Control & $95.8^{\mathrm{u}}$ & 56.0 & 0.44 & 10.2 & 1.34 & 3.79 & $19.92 \mathrm{~b}$ & 190.2 \\
\hline White & 102.6 & 56.8 & 0.48 & 9.8 & 1.37 & 3.77 & $22.53 \mathrm{ab}$ & 186.9 \\
\hline Black & 98.1 & 56.9 & 0.47 & 9.8 & 1.46 & 3.76 & $29.79 \mathrm{ab}$ & 243.8 \\
\hline Blue & 95.6 & 56.0 & 0.60 & 10.3 & 1.52 & 3.72 & $29.68 \mathrm{ab}$ & 198.7 \\
\hline Green & 87.7 & 54.5 & 0.59 & 10.0 & 1.46 & 3.78 & $33.11 \mathrm{ab}$ & 236.1 \\
\hline Red & 99.8 & 56.7 & 0.54 & 10.4 & 1.45 & 3.77 & $35.70 \mathrm{a}$ & 211.7 \\
\hline $\mathrm{SEM}^{\mathrm{t}}$ & 4.1 & 0.9 & 0.07 & 0.2 & 0.06 & 0.02 & 3.51 & 22.3 \\
\hline$P$ value & 0.174 & 0.378 & 0.403 & 0.239 & 0.295 & 0.474 & 0.012 & 0.332 \\
\hline
\end{tabular}

${ }^{\mathrm{z}}$ Unit less difference of absorbance (DA) index measurement of chlorophyll- $\alpha$ (Spadoni et al., 2016).

${ }^{\mathrm{y}} \mathrm{TSS}=$ total soluble solids

${ }^{\mathrm{x}} \mathrm{TA}=$ total titratable acidity.

${ }^{\mathrm{w}} \mathrm{pH}$ values represent the median.

${ }^{\mathrm{v}} \mathrm{C}-3-\mathrm{G}=$ anthocyanin concentration of cyaniding-3-glucoside.

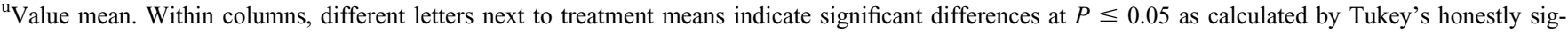
nificant difference test.

${ }^{\mathrm{t}} \mathrm{SEM}=$ standard error of the mean.

harvest on 29 Apr. Zero insects were found in the color-baited traps, but predatory male and female regal jumping spiders, Phidipus regius C.L. Koch, were collected in greenand blue-baited traps on 26 Mar. 2019.

\section{Discussion}

Air temperature, RH, and WVP. The results of this study are consistent with peach and apple bagging studies in which increased air temperatures were observed inside fruit bags (Li et al., 2001; Morandi et al., 2010; Ritenour et al., 1997), but contrast with other studies of bagged peaches in which similar or lower internal bag air temperatures were observed (Zhang et al., 2015). In this study, all bagged fruit were on the canopy perimeter and the air temperature inside the bags exceeded $14^{\circ} \mathrm{C}$ above ambient temperature during specific dates/times. The maximum observed temperatures were generally between 35 and $40^{\circ} \mathrm{C}$ for all color treatments. Increased temperatures can alter stomatal aperture, photosynthetic capacity, and other responses that are species and cultivar dependent. The maximum

temperatures observed would promote a higher carbon assimilation rate of Rubisco (Salvucci et al., 2001), but would not denature peroxidases (Neves and Lourenço, 1998) or polyphenol oxidase in peach (Garro and Gasull, 2010).

Low-chill peaches, such as 'UFSun' and 'TropicBeauty', can be damaged by earlyseason freezes that kill developing buds and fruitlets, and an increase in carposphere temperature would mitigate that risk. We did not observe any freezing temperatures in 2019, but in the early mornings on 21 Mar. and 22 Mar., the ambient temperatures fell below $5^{\circ} \mathrm{C}$ for at least $15 \mathrm{~min}$ between $0400 \mathrm{HR}$ and $0700 \mathrm{HR}$. Unfortunately, the temperature inside the bags was not elevated during this time frame, and although bags may reduce evaporative cooling of fruit during freezes accompanied by wind, early-season freeze protection is not likely.

During the harvests, the average bagging temperature was above $35^{\circ} \mathrm{C}$ with an $\mathrm{RH}$ below $40 \%$ for at least $3 \mathrm{~h}$ between $25 \mathrm{Apr}$. and 1 May. Casals et al. (2010) demonstrated that an optimum postharvest curing treatment to protect peaches against the causative agent

Table 2. Peel and flesh color attributes of 'Tropic Beauty' peach fruit grown inside white paper bags (no filter) with photoselective filters to alter the spectrum black $(>725 \mathrm{~nm})$, blue $(400-500 \mathrm{~nm})$, green $(500-600 \mathrm{~nm})$, and red $(>600 \mathrm{~nm})$ relative to full-spectrum light at Marion and Lake Counties in central Florida in 2019.

\begin{tabular}{lccccccc}
\hline & \multicolumn{3}{c}{ Peel } & & \multicolumn{3}{c}{ Flesh } \\
\cline { 2 - 4 } \cline { 6 - 7 } Bag color & $\mathrm{L}^{\mathrm{z}}$ & $\mathrm{h}^{\mathrm{y}}$ & $\mathrm{C}^{\mathrm{x}}$ & & $\mathrm{L}$ & $\mathrm{h}$ & $\mathrm{C}$ \\
\hline Control & $48.50^{\mathrm{w}}$ & 46.98 & $43.77 \mathrm{a}$ & & 69.23 & 83.90 & 59.06 \\
White & 49.94 & 47.68 & $42.41 \mathrm{ab}$ & & 69.73 & 84.32 & 58.66 \\
Black & 47.87 & 45.10 & $42.04 \mathrm{ab}$ & & 71.03 & 85.54 & 56.32 \\
Blue & 48.10 & 45.41 & $41.40 \mathrm{ab}$ & & 71.31 & 86.04 & 57.75 \\
Green & 47.22 & 44.18 & $40.23 \mathrm{~b}$ & & 70.52 & 85.37 & 57.75 \\
Red & 47.80 & 45.42 & $42.98 \mathrm{ab}$ & & 71.05 & 85.42 & 57.94 \\
SEM & 1.24 & 2.05 & 0.81 & & 0.98 & 0.70 & 0.79 \\
$P$ value & 0.728 & 0.853 & 0.044 & & 0.561 & 0.613 & 0.217 \\
\hline
\end{tabular}

${ }^{\mathrm{z}} \mathrm{L}=$ lightness range from 0 (black) to 100 (white).

${ }^{\mathrm{y}} \mathrm{h}=$ hue angle that represents color ranging from 0 to 360 degrees with colors equivalent to 0 (red), 90 (yellow), 180 (green), and 270 (blue).

${ }^{\mathrm{x}} \mathrm{C}=$ color saturation or intensity from 0 (gray) to 60 (full saturation/intensity).

${ }^{\mathrm{w}}$ Values are the means. Within columns, different letters next to treatment means indicate significant differences at $P \leq 0.05$ as calculated by Tukey's honestly significant difference test.

${ }^{\mathrm{v}} \mathrm{SEM}=$ standard error of the mean. of brown rot (Monilinia fructicola) was a onetime treatment at $50{ }^{\circ} \mathrm{C}$ for $2 \mathrm{~h}$ at $\mathrm{RH}$ levels above $90 \%$. They also found that protection against $M$. fructicola was observed when the temperature/RH was $40{ }^{\circ} \mathrm{C} / 85 \%$ for $4 \mathrm{~h}$ and at $50{ }^{\circ} \mathrm{C} / 65 \%$ for $2 \mathrm{~h}$. Future scientists need to consider and control for bagging materials that may alter the WVP inside the bags and possibly confound the results. Information on a wider range of temperature, $\mathrm{RH}, \mathrm{WVP}$, and treatment durations to reduce $M$. fructicola growth and injury is needed to determine if the protective effects observed from bagging in Florida (Campbell et al., 2021) are due to a physical barrier preventing spore deposition on the fruit surface, a potential in situ curing with multiple days/hours at an increased temperature, or a combination of both.

The diurnal $\mathrm{RH}$ and temperature changes were expected, but the increased WVP in the bags that contained plastic inserts provide evidence that air flow may have been restricted. The lack of other quality changes suggests that increased WVP surrounding bagged peaches may not have any biological significance.

Shading, photosynthesis, and fruit quality. Although the higher temperature inside bags may lead to an increased activity of Rubisco and an overall increase in photosynthetic activity in the green fruit, shading counteracts these benefits (Chen and Cheng, 2007; Pavel and DeJong, 1993). The increased shading with PAR values as low as $73 \mu \mathrm{mol} \cdot \mathrm{m}^{-2} \cdot \mathrm{s}^{-2}$ in this study combined with the lack of fruit fresh weight differences suggests that the potential lack of carbon assimilation by the green fruit was likely offset by carbohydrate production elsewhere in the tree.

In addition to natural shading by the canopy, the color bagging treatments shaded fruit with $P A R$ values relative to full sun of $3.7 \%$, $12.7 \%, 16.6 \%, 17.4 \%$, and $50.3 \%$ for the black, blue, green, red, and white treatments, respectively. The photosynthetic rate saturation for ' $C a l$ Red' peach was reported to be 600 $\mu \mathrm{mol} \cdot \mathrm{m}^{-2} \cdot \mathrm{s}^{-2}$ (Pavel and DeJong, 1993), but the only bagging treatment in the current study that exceeded that rate was the white bag $\left(1000 \mu \mathrm{mol} \cdot \mathrm{m}^{-2} \cdot \mathrm{s}^{-2}\right)$, whereas all others 

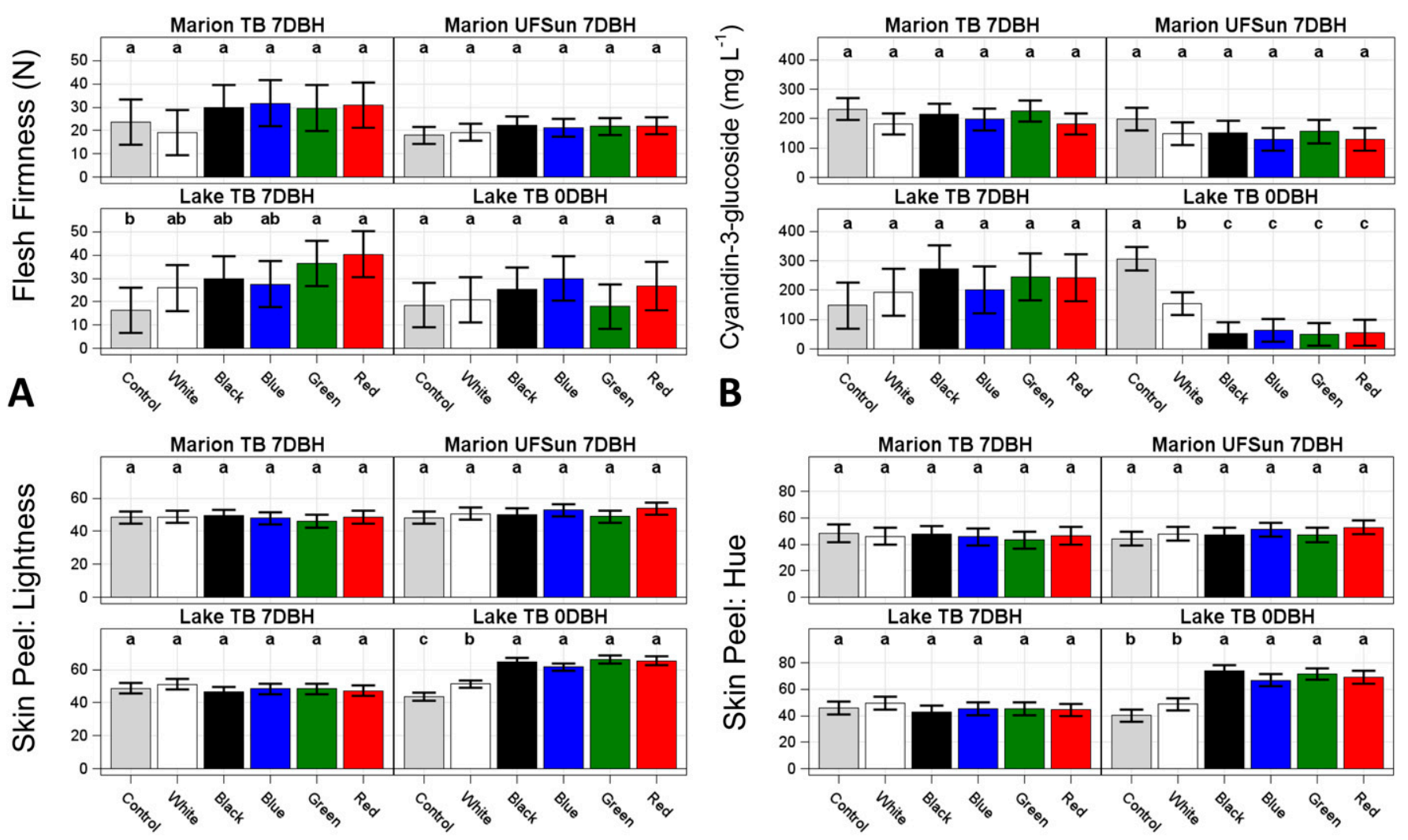

C

Bag Color

D

Bag Color

Fig. 5. Site combination above each graph for flesh firmness (A), anthocyanin (cyanidin-3-glucoside) concentration (B), peel lightness (C), and peel hue (D) for peaches grown in Marion County (Marion) or Lake County (Lake); cultivars 'Tropic Beauty' ('TB') or 'UFSun'; with bag removal at $7 \mathrm{~d}$ before harvest $(7 \mathrm{DBH})$ or not removed until harvest $(0 \mathrm{DBH})$ in 2019 . Error bars represent the $95 \%$ confidence interval and each site combination was analyzed separately. Different letters above each mean are significantly different $(P<0.05)$ according to Tukey's honestly significant difference.

received, at most, $57.8 \%$ (red bag) of the 600 $\mu \mathrm{mol} \cdot \mathrm{m}^{-2} \cdot \mathrm{s}^{-2}$ saturation requirement. This suggests that the color treatments were all being "grown in the dark" and contributed proportionately less to the total photosynthetic capacity of the tree, but additional research on low-chill cultivar photosynthetic saturation amounts are needed to confirm this assumption.

Fruit physical, chemical, and nutritional attributes. Using different-colored bags has shown mixed results on fruit quality for a variety of crops (Sharma et al., 2014), but the results from this experiment only showed that flesh firmness was increased when fruit were grown in red bags, and peel chroma was decreased when they were grown in green bags. Zhang et al. (2015) used white and black paper and polypropylene bags, removed the bags $7 \mathrm{DBH}$, and generally found that bagging treatments increased the peel chroma, reduced peel lightness, and reduced peel hue. Peel chroma was found to decline during postharvest, as evidenced by the reduction from 44 to 39 when low-chill 'Flordaking' peach fruit were stored at $0 \pm$ $0.3^{\circ} \mathrm{C}$ up to 5 weeks (Tareen et al., 2012). Lower chroma was associated with accelerated ripening of peach and plum fruits (Guillén et al., 2013), but it is unlikely that the fruit in green bags were ripening faster than other treatments given the high flesh firmness and DA Index values.
Compared with the unbagged control, the greater firmness observed for fruit in red bags is consistent with a numerical firmness increase for other bagging treatments in this study and some (Campbell et al., 2021; Zhang et al., 2015), but not all (Wang et al., 2010), peach bagging studies. Red light with a peak at $660 \mathrm{~nm}$ converts phytochrome B from the inactive form $\left(\mathrm{P}_{\mathrm{r}}\right)$ to the active form $\left(\mathrm{P}_{\mathrm{fr}}\right)$ and can be converted back to $\mathrm{P}_{\mathrm{r}}$ with light at $730 \mathrm{~nm}$, or naturally over extended periods of time without light. The red bag had a photochemical equilibration ratio of 0.84:1 (Schäfer and Nagy, 2006) and a fluence rate of $73 \mu \mathrm{mol} \cdot \mathrm{m}^{-2} \cdot \mathrm{s}^{-1}$ in the wavelength range of $660 \pm 5 \mathrm{~nm}$. By comparison,

Table 3. Total nutrients of whole fruit on a dry weight basis for 'Tropic Beauty' peach grown in Central Florida (Marion or Lake County) in 2019.

\begin{tabular}{|c|c|c|c|c|c|c|c|c|c|c|c|c|c|}
\hline & & $\mathrm{N}$ & $\mathrm{S}$ & $\mathrm{P}$ & $\mathrm{K}$ & $\mathrm{Mg}$ & $\mathrm{Ca}$ & $\mathrm{Na}$ & B & $\mathrm{Zn}$ & $\mathrm{Mn}$ & $\mathrm{Fe}$ & $\mathrm{Cu}$ \\
\hline & & \multicolumn{7}{|c|}{$(\%)$} & \multicolumn{5}{|c|}{ (ppm) } \\
\hline \multirow[t]{2}{*}{ Skin } & Marion & 1.157 & 0.072 & 0.138 & 1.294 & 0.090 & 0.165 & 0.011 & 36.292 & 9.875 & 6.442 & 25.000 & 1.875 \\
\hline & Lake & 0.812 & 0.053 & 0.102 & 1.074 & 0.063 & 0.059 & 0.011 & 31.167 & 10.250 & 4.708 & 33.542 & 9.167 \\
\hline \multirow[t]{3}{*}{ Flesh } & Marion & 0.988 & 0.059 & 0.185 & 1.967 & 0.074 & 0.098 & 0.018 & 40.250 & 8.750 & 5.750 & 28.250 & 4.000 \\
\hline & Lake & 0.599 & 0.050 & 0.159 & 1.673 & 0.063 & 0.086 & 0.026 & 32.167 & 11.542 & 5.250 & 30.333 & 10.833 \\
\hline & $P$ value & $<0.001$ & 0.293 & $<0.001$ & 0.001 & 0.002 & 0.022 & 0.154 & 0.007 & 0.001 & 0.304 & 0.769 & $<0.001$ \\
\hline Pit & $P$ value & 0.085 & 0.048 & 0.654 & 0.116 & 0.120 & 0.136 & 0.503 & 0.877 & 0.792 & 0.058 & 0.200 & 0.345 \\
\hline
\end{tabular}

The nutrients nitrogen $(\mathrm{N})$, sulfur $(\mathrm{S})$, phosphorus $(\mathrm{P})$, potassium $(\mathrm{K})$, magnesium $(\mathrm{Mg})$, calcium $(\mathrm{Ca})$, and sodium $(\mathrm{Na})$ are reported as a percent $(\%)$ of the total fruit. The nutrients boron $(\mathrm{B})$, zinc $(\mathrm{Zn})$, manganese $(\mathrm{Mn})$, iron $(\mathrm{Fe})$, and copper $(\mathrm{Cu})$ are reported as parts per million (ppm). 
the unbagged control had a photochemical equilibration ratio of 1.04:1 $\left(\mathrm{P}_{\mathrm{r}}: \mathrm{P}_{\mathrm{fr}}\right)$ with a fluence of $170 \mu \mathrm{mol} \cdot \mathrm{m}^{-2} \cdot \mathrm{s}^{-1}$. A lower $\mathrm{P}_{\mathrm{r}}: \mathrm{P}_{\mathrm{fr}}$ ratio has been associated with the "shadeavoidance syndrome" with observed stem elongation (Ruberti et al., 2012). Given that fruit contain phytochrome, it is possible that a similar elongation to intercept unattenuated light may occur. The lack of diameter and fresh weight differences does not suggest that a different growth pattern (and corresponding tissue density) explains the firmness difference observed.

Liu et al. (2015) found that use of white polypropylene bags for 'Yulu' peaches resulted in higher anthocyanin concentration compared with unbagged fruit, as well as fruit bagged with blue polypropylene, gray polypropylene, black polypropylene, or yellow paper bags, and found that white and unbagged 'Hujingmilu' peaches had increased anthocyanin content relative to other colored bags. Their white polypropylene bag had a light transmittance of $90 \%$ at $300 \mathrm{~nm}$ with a gradual reduction to $75 \%$ at $750 \mathrm{~nm}$. The white paper bags used for the present study allowed $50 \%$ PAR transmittance that followed the same spectral pattern as full sun, but the colored bag treatments permitted only a narrow range of wavelengths with lower transmission rates (PAR between $3.7 \%$ and $17.4 \%$ ) compared with full sun. The protocol used by Zhang et al. (2015) was similar to the bag removal treatment in this experiment that did not expose the fruit to the sun until 7 $\mathrm{DBH}$, and the findings support the direct association between light transmission rates and anthocyanin concentration. These combined results provide support that anthocyanin production in field bagging conditions requires full sunlight for maximum expression, may be directly related to incident $P A R$, and does not maintain or increase production in the presence of light restricted within specific spectral ranges. Photoreceptor activity for phytochrome B (Kretsch and Schäfer, 2000; Rausenberger et al., 2010), cryptochromes (Bouly et al., 2007; Procopio et al., 2016), and phototropins (Inoue et al., 2008) are fluence ratedependent and more work is needed to determine if a sufficient quantity of light was being transmitted to elicit a response under these experimental conditions.

Nutrient assimilation. The lack of nutrient and compositional differences between peaches grown in a white paper bag vs. in full sun is a positive result for growers interested in maintaining peach fruit quality. The differences observed by location, which may be due to soil, meteorological conditions, or other management practices, show that peach nutrient concentration may be sensitive to these changes. Although $\mathrm{Cu}$ was significantly elevated in the fruit peel and flesh in Lake County, the opposite was observed in the leaves (data not shown but will be available online at the UF dissertation repository in 2023). Leaf samples collected in Lake County had $\mathrm{Cu}$ in the sufficiency range (5-16 ppm; Johnson, 2008) with a value of $6.5 \mathrm{ppm}$ $\mathrm{Cu}$ as compared with $2 \mathrm{ppm} \mathrm{Cu}$ in Marion
County. Before conversion to a peach orchards, the past land uses in Marion and Lake Counties were pasture and citrus production, respectively. According to our farmer collaborator, the prevalence of $\mathrm{Cu}$ based agricultural sprays resulted in the elevated soil $\mathrm{Cu}$ concentration of $23.3 \mathrm{mg} \cdot \mathrm{kg}^{-1}$ observed at the Lake County location as compared with reduced $\mathrm{Cu}$ sprays and reduced soil $\mathrm{Cu}$ concentration of $0.2 \mathrm{mg} \cdot \mathrm{kg}^{-1}$ at the Marion County location. The increased soil $\mathrm{Cu}$ concentration might explain the correlation with fruit $\mathrm{Cu}$ concentration, but the intree fruit and vegetative allocation of $\mathrm{Cu}$ deserves further exploration.

\section{Conclusion}

The overall lack of fruit quality differences when growing peaches in bags is promising when considering the pest and disease management benefits, but more research is needed to determine if fruit quality can be enhanced with different-colored bags. Minimum fluence rates to ensure photoreceptor activity and elicitation of a response for fieldgrown peaches is needed. Additional questions that would further this research area include the following: Does light wavelength influence $M$. fructicola or other biological growth and potential infection rate ( $\mathrm{Yu}$ and Lee, 2013)? Does light wavelength influence fruit volatile production that may attract arthropod pest activity or enhance fruit flavor? How do the interacting elements of temperature, $\mathrm{RH}$, and light quality influence the photosynthetic capacity, downstream biochemical reactions, and stomatal conductance of peach fruit? As bagging research matures, we believe ideal materials and methods will become evident, and researchers along with industry would benefit from using standardized protocols and bagging materials to compare results among regions, crops, and pest/ disease complexes.

\section{Literature Cited}

Allran, J., G. Schnabel, and J.C. Melgar. 2019. Peach bagging in the Southeastern US. J. Amer. Soc. Hort. Sci. 73:38-46.

Amoozgar, A., A. Mohammadi, and M.R. Sabzalian. 2017. Impact of light-emitting diode irradiation on photosynthesis, phytochemical composition and mineral element content of lettuce cv. Grizzly. Photosynthetica 55:85-95, https://doi.org/ 10.1007/s11099-016-0216-8.

Bae, S., H. Yi, Y. Yoon, Y. Jang, Y. Kim, and R. Maharjan. 2019. Attraction of stink bugs to rocket traps with different combinations of wing and landing board color. J. Asia Pac. Entomol. 22:243-249, https://doi.org/10.1016/j.aspen.2019. 01.007

Bastías, R. and L. Corelli-Grappadelli. 2012. Light quality management in fruit orchards: Physiological and technological aspects. Chil. J. Agr. Res. 72:574-581.

Bouly, J.-P., E. Schleicher, M. Dionisio-Sese, F. Vandenbussche, D.V.D. Straeten, N. Bakrim, S. Meier, A. Batschauer, P. Galland, R. Bittl, and M. Ahmad. 2007. Cryptochrome blue light photoreceptors are activated through interconversion of flavin redox states. J. Biol. Chem. 282:
9383-9391, https://doi.org/10.1074/jbc.M60984 2200.

Campbell, D., A. Sarkhosh, J. Brecht, J. GillettKaufman, O. Liburd, J.C. Melgar, and D. Treadwell. 2021. Fruit bagging improves quality and shelf life of organic peach in Florida. Hort Science 56:52-58, https://doi.org/10.21273/ HORTSCI15391-20.

Casals, C., N. Teixidó, I. Viñas, S. Llauradó, and J. Usall. 2010. Control of Monilinia spp. on stone fruit by curing treatments: Part I. The effect of temperature, exposure time and relative humidity on curing efficacy. Postharvest Biol. Technol. 56:19-25, https://doi.org/10.1016/j.postharvbio. 2009.11.008

Chang, Y., A. Sarkhosh, J. Brechtas, and P. Anderson. 2018. Thinning Florida peaches for larger fruit. HS1324. University of Florida Institute of Food and Agricultural Sciences, Gainesville, https://edis.ifas.ufl.edu/hs1324.

Chen, L.S. and L. Cheng. 2007. The sun-exposed peel of apple fruit has a higher photosynthetic capacity than the shaded peel. Funct. Plant Biol. 34:1038-1048, https://doi.org/10.1071/FP07111.

Chia, P.L. and C. Kubota. 2010. End-of-day farred light quality and dose requirements for tomato rootstock hypocotyl elongation. HortScience 45:1501-1506, https://doi.org/10.21273/ HORTSCI.45.10.1501.

FAWN. 2019. Florida Automated Weather Network Report Generator. University of Florida Gainesville Florida. 10 Nov. 2019. <http:// fawn.ifas.ufl.edu/data/reports/ $>$.

Folta, K.M. and S.D. Carvalho. 2015. Photoreceptors and control of horticultural plant traits. HortScience 50:1274-1280, https://doi.org/ 10.21273/HORTSCI.50.9.1274.

Garro, A. and E. Gasull. 2010. Characterization of polyphenoloxidase from 2 peach (Prunus persica L.) varieties grown in Argentina. Food Sci. Biotechnol. 19:627-632, https://doi.org/ 10.1007/s10068-010-0088-9.

Guillén, F., H.M. Díaz-Mula, P.J. Zapata, D. Valero, M. Serrano, S. Castillo, and D. Martínez-Romero. 2013. Aloe arborescens and Aloe vera gels as coatings in delaying postharvest ripening in peach and plum fruit. Postharvest Biol. Technol. 83:54-57, https://doi. org/10.1016/j.postharvbio.2013.03.011.

Hogmire, H.W. and T.C. Leskey. 2006. An improved trap for monitoring stink bugs (Heteroptera: Pentatomidae) in apple and peach orchards. J. Entomol. Sci. 41:9-21, https://doi. org/10.18474/0749-8004-41.1.9.

Holopainen, J.K., M. Kivimäenpää, and R. Julkunen-Tiitto. 2018. New light for phytochemicals. Trends Biotechnol. 36:7-10, https://doi.org/ 10.1016/j.tibtech.2017.08.009.

Inoue, S., T. Kinoshita, M. Matsumoto, K.I. Nakayama, M. Doi, and K. Shimazaki. 2008 Blue light-induced autophosphorylation of phototropin is a primary step for signaling. Proc. Natl. Acad. Sci. USA 105:5626-5631, https:// doi.org/10.1073/pnas.0709189105.

Johnson, C.F., C.S. Brown, R.M. Wheeler, J.C. Sager, D.K. Chapman, and G.F. Deitzer. 1996. Infrared light-emitting diode radiation causes gravitropic and morphological effects in darkgrown oat seedlings. Photochem. Photobiol. 63: 238-242, https://doi.org/10.1111/j.1751-1097. 1996.tb03020.x.

Johnson, R.S. 2008. Nutrient and water requirements of peach trees, p. 303-321. In: D.R. Layne and D. Bassi (eds.). The peach: Botany, production and uses. $\mathrm{CAB}$ International, Cambridge, MA

Jurd, L. and S. Asen. 1966. The formation of metal and "co-pigment" complexes of cyanidin 3- 
glucoside. Phytochemistry 5:1263-1271, https://doi.org/10.1016/S0031-9422(00) 86122-1.

Kasperbauer, M.J. 2000. Strawberry yield over red versus black plastic mulch. Crop Sci. 40: 171-174, https://doi.org/10.2135/cropsci2000. 401171x.

Kemp, E.A. and T.E. Cottrell. 2015. Effect of lures and colors on capture of lady beetles (Coleoptera: Coccinellidae) in Tedders pyramidal traps. Environ. Entomol. 44:1395-1406, https://doi. org/10.1093/ee/nvv108.

Kretsch, T.C.P. and E. Schäfer. 2000. A new type of mutation in the plant photoreceptor phytochrome B causes loss of photoreversibility and an extremely enhanced light sensitivity. Plant $\mathrm{J}$. 22:177-186, https://doi.org/10.1046/j.1365-313x. 2000.00715.x.

Lee, J., R.W. Durst, and R.E. Wrolstad. 2005. Determination of total monomeric anthocyanin pigment content of fruit juices, beverages, natural colorants, and wines by the $\mathrm{pH}$ differential method: Collaborative study. J. AOAC Intl. 88:1269-1278.

Leskey, T.C. and H.W. Hogmire. 2005. Monitoring stink bugs (Hemiptera: Pentatomidae) in mid-Atlantic apple and peach orchards. J. Econ. Entomol. 98:143-153, https://doi.org/ 10.1111/j.1570-7458.2007.00545.x.

Li, Q. and C. Kubota. 2009. Effects of supplemental light quality on growth and phytochemicals of baby leaf lettuce. Environ. Expt. Bot. 67:59-64.

Li, S.H., M. Genard, C. Bussi, J.G. Huguet, R. Habib, J. Besset, and J. Laurent. 2001. Fruit quality and leaf photosynthesis in response to microenvironment modification around individual fruit by covering the fruit with plastic in nectarine and peach trees. J. Hort. Sci. Biotechnol. 76:61-69, https://doi.org/10.1016/j.envexpbot. 2009.06.011.

Liu, T., S. Song, Y. Yuan, D. Wu, M. Chen, Q. Sun, B. Zhang, C. Xu, and K. Chen. 2015. Improved peach peel color development by fruit bagging. Enhanced expression of anthocyanin biosynthetic and regulatory genes using white non-woven polypropylene as replacement for yellow paper. Scientia Hort. 184:142-148, https://doi.org/10.1016/j.scienta.2015.01.003.

Magerøy, M.H., E.H. Kowalik, K.M. Folta, and J. Shinkle. 2010. Evidence of physiological phototropin1 (phot1) action in response to UV-C illumination. Plant Signal. Behav. 5:1204-1210, https://doi.org/10.4161/psb.5.10.12413.

Manja, K. and M. Aoun. 2019. The use of nets for tree fruit crops and their impact on the production: A review. Scientia Hort. 246:110-122, https://doi.org/10.1016/j.scienta.2018.10.050.

Miao, L., Y. Zhang, X. Yang, J. Xiao, H. Zhang, Z. Zhang, Y. Wang, and G. Jiang. 2016. Colored light-quality selective plastic films affect anthocyanin content, enzyme activities, and the expression of flavonoid genes in strawberry (Fragaria $\times$ ananassa) fruit. Food Chem. 207:93-100, https://doi.org/10.1016/j.foodchem. 2016.02.077.
Mizuno, T., W. Amaki, and H. Watanabe. 2011. Effects of monochromatic light irradiation by LED on the growth and anthocyanin contents in leaves of cabbage seedlings. Acta Hort. 907:179-184.

Morandi, B., L. Manfrini, P. Losciale, M. Zibordi, and L. Corelli-Grappadelli. 2010. The positive effect of skin transpiration in peach fruit growth. J. Plant Physiol. 167:1033-1037, https://doi.org/10.1016/j.jplph.2010.02.015.

Mupambi, G., B.M. Anthony, D.R. Layne, S. Musacchi, S. Serra, T. Schmidt, and L.A. Kalcsits. 2018. The influence of protective netting on tree physiology and fruit quality of apple: A review. Scientia Hort. 236:60-72, https://doi. org/10.1016/j.scienta.2018.03.014.

Neves V.A., E.J. Lourenço. 1998. Peroxidase from peach fruit: Thermal stability. Brazilian Arch. Biol. Technol. 41:1-9, https://doi.org/10.1590/ S1516-89131998000200002

Olle, M. and A. Viršile. 2013. The effects of lightemitting diode lighting on greenhouse plant growth and quality. Agr. Food Sci. 22:223-234, https://doi.org/10.23986/afsci.7897.

Pavel, E.W. and T.M. DeJong. 1993. Estimating the photosynthetic contribution of developing peach (Prunus persica) fruits to their growth and maintenance carbohydrate requirements. Physiol. Plant. 88:331-338, https://doi.org/ 10.1111/j.1399-3054.1993.tb05507.x.

Procopio, M., J. Link, D. Engle, J. Witczak, T. Ritz, and M. Ahmad. 2016. Kinetic modeling of the Arabidopsis cryptochrome photocycle: $\mathrm{FADH}^{\mathrm{o}}$ accumulation correlates with biological activity. Frontiers Plant Sci. 7(888):1-16, https://doi.org/10.3389/fpls.2016.00888.

Rausenberger, J., A. Hussong, S. Kircher, D. Kirchenbauer, J. Timmer, F. Nagy, E. Schäfer, and C. Fleck. 2010. An integrative model for phytochrome B mediated photomorphogenesis: From protein dynamics to physiology. PLoS One 5(5.e10721):1-13, https://doi.org/10.1371/ journal.pone.0010721.

Reyes, T.H., E. Esparza, G. Crestani, F. Limonchi, R. Cruz, N. Salinas, A. Scartazza, L. Guglielminetti, and E. Cosio. 2020. Physiological responses of maca (Lepidium meyenii Walp.) plants to UV radiation in its high-altitude mountain ecosystem. Sci. Rpt. 10:1-13.

Ritenour, M., L. Schrader, R. Kammereck, R. Donahue, and G. Edwards. 1997. Bag and liner color greatly affect apple temperature under full sunlight. HortScience 32:272-276.

Ruberti, I., G. Sessa, A. Ciolfi, M. Possenti, M. Carabelli, and G. Morelli. 2012. Plant adaptation to dynamically changing environment: The shade avoidance response. Biotechnol. Adv. 30:10471058, https://doi.org/10.1016/j.biotechadv.2011. 08.014.

Salvucci, M.E., K.W. Osteryoung, S.J. CraftsBrandner, and E. Vierling. 2001. Exceptional sensitivity of Rubisco activase to thermal denaturation in vitro and in vivo. Plant Physiol. 127:1053-1064.

Samuoliene, G., A. Brazaityte, R. Sirtautas, A Novičkovas, and P. Duchovskis. 2012. The effect of supplementary LED lighting on the antioxidant and nutritional properties of lettuce. Acta Hort. (952):835-842.

Schäfer, E. and F. Nagy (eds.). 2006. Photomorphogenesis in plants and bacteria: Function and signal transduction mechanisms. Springer-Verlag, New York, NY.

Shahak, Y., E.E. Gussakovsky, Y. Cohen, S. Lurie, R. Stern, S. Kfir, A. Naor, I. Atzmon, I. Doron, and Y. Greenblat-Avron. 2004. Colornets: A new approach for light manipulation in fruit trees. Acta Hort. 609-616.

Sharma, R.R., S.V.R. Reddy, and M.J. Jhalegar. 2014. Pre-harvest fruit bagging: A useful approach for plant protection and improved post-harvest fruit quality. J. Hort. Sci. Biotechnol. 89:101-113.

Sharma, R.R. and V.R. Sanikommu. 2018. Preharvest fruit bagging for better protection and postharvest quality of horticultural produce, $\mathrm{p}$. 455-489. In: M.W. Siddiqui (ed.). Preharvest modulation of postharvest fruit and vegetable quality. Academic Press, San Diego, CA. https:// doi.org/10.1016/B978-0-12-809807-3.00016-0.

Spadoni, A., I. Cameldi, M. Noferini, E. Bonora, G. Costa, and M. Mari. 2016. An innovative use of DA-meter for peach fruit postharvest management. Sci. Hort. 201:140-144, https:// doi.org/10.1016/S0304-4238(97)00125-8.

Stutte, G.W., S. Edney, and T. Skerritt. 2009. Photoregulation of bioprotectant content of red leaf lettuce with light-emitting diodes. HortScience 44: 79-82, https://doi.org/10.21273/HORTSCI.44. 1.79 .

Tareen, M.J., N.A. Abbasi, and I.A. Hafiz. 2012 Postharvest application of salicylic acid enhanced antioxidant enzyme activity and maintained quality of peach cv. 'Flordaking' fruit during storage. Scientia Hort. 142:221-228, https:// doi.org/10.1016/j.scienta.2012.04.027.

Wang, Y., C. Yang, C. Liu, M. Xu, S. Li, L. Yang, and Y. Wang. 2010. Effects of bagging on volatiles and polyphenols in 'Wanmi' peaches during endocarp hardening and final fruit rapid growth stages. J. Food Sci. 75:S455-S460, https://doi. org/10.1111/j.1750-3841.2010.01817.x.

Wang, Y. and K.M. Folta. 2013. Contributions of green light to plant growth and development. Amer. J. Bot. 100:70-78, https://doi.org/10.3732/ ajb. 1200354

Yang, Z.C., C. Kubota, P.L. Chia, and M. Kacira. 2012. Effect of end-of-day far-red light from a movable LED fixture on squash rootstock hypocotyl elongation. Scientia Hort. 136:81-86, https://doi.org/10.1016/j.scienta.2011.12.023.

Yu, S.M. and Y.H. Lee. 2013. Effect of light quality on Bacillus amyloliquefaciens JBC36 and its biocontrol efficacy. Biol. Control 64:203-210, https://doi.org/10.1016/j.biocontrol.2012.11.004.

Zhang, B.B., J.Y. Guo, R.J. Ma, Z.X. Cai, J. Yan, and C.H. Zhang. 2015. Relationship between the bagging microenvironment and fruit quality in 'Guibao' peach [Prunus persica (L.) Batsch]. J. Hort. Sci. Biotechnol. 90:303-310, https:// doi.org/10.1080/14620316.2015.11513187. 